\title{
Rainfall tables for China and Korea.
}

\author{
By T. QKaDA.
}

I. Introductory.-Since the publication of Dr. Fritsche's admirable treatise on the climate of eastern Asia, contributions to the knowledge of the climate of China, especially in connection with the rainfall have been made by several authorities as Thirrling, Hann, Supan, and Doberck. Among others, Prof. Supan collected the results of pluviometric observations made at Chinese lighthouses and custom houses together with those taken at Pekin, Zikawei and Hongkong meteorological observatories, and published the result of his elaborate discussion in the well known Petermann's Geographische Mittheilungen. This monography by the German geographer is indeed the most complete of all the similar works which we have at present. But since the publication of that memoir, several years have elapsed, and now we can obtain the longer years' mean of rainfall at some forty stations in Eastern China and Korean Empire, instead of the six. years' mean at a smaller number of stations, by which Prof. Supan has drawn up his conclusion on the pluviometric conditions of the vast celestial empire. It may not be therefore needless duplication to publish here a collection of the more recent observations for the ten years from 1892 to IgQI.

The materials used are the rainfall-tables given in the successive volumes of the excellent Bulletins of L'Observatoire du mètèorologie et Magntismus de Zikawei for the years from 1892 to I90I. These tables contain only daily sums of precipitation at some thirty stations on China and Korea coasts, which are composed of custom houses, lighthouses and meteorological observatories. We have therefore enumerated the 
numbers of days with rain, and extracted the greatest daily rainfall for each montl from the tables. The data for Tingtam, Wei-hai-wei and Foochow are taken from other sources. Rainfall-tables in China published by Dr. Doberck in the early numbers of Quarterly journal of Meteorological Society and reports of the Hongkong Observatory are also consulted.

2. Annual rainfall.-We give in the following table the mean annual rainfall at thirty-seven stations in China and three stations in Korea. Most of these stations are situated on the coasts or in the neighbouring islands, and only a few stations have continental situation, so that our data are professedly insufficient for the study of the geographical distributions of rainfall in the Empire. The mean annual rainfall here given are mostly deduced from the ten years' observations, and only a few of them refer to the measurements of a shorter duration. But we have abstained from the reducing them to the corresponding ten years' means, as is usual in the pluviometric investigations, simply because we have not sufficient data for it.

\section{Table I. ANNUAL RAINFALL.}

\begin{tabular}{|c|c|c|c|}
\hline Stations. & Latitude. & Iongitude. & $\begin{array}{l}\text { Annual } \\
\text { rainfall. }\end{array}$ \\
\hline Peling (北京) & $39^{\circ} 57^{\prime}$ & $116^{\circ} 28^{\prime}$ & 675.9 \\
\hline$\ldots \ldots \ldots \ldots \ldots \ldots \ldots$ & 399 & 12733 & 1138.1 \\
\hline 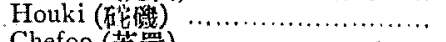 & 384 & 12039 & 423.2 \\
\hline 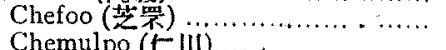 & 3734 & I2I 32 & 582.6 \\
\hline 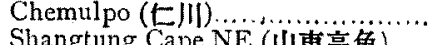 & 3729 & I26 37 & 905.2 \\
\hline & 3724 & $\mathrm{I} 2242$ & $536 . \mathrm{I}$ \\
\hline Shangtung Cape SE (南秉高角) & 3724 & $1224^{2}$ & 671.9 \\
\hline & 37 Io & $x 22$ io & 535.5 \\
\hline 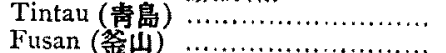 & 364 & I20 I 8 & 682.6 \\
\hline $\begin{array}{l}\text { Fusan (釡山) } \\
\text { Chinkiang (䣄沅) }\end{array}$ & 355 & I29.6 & I 136.3 \\
\hline 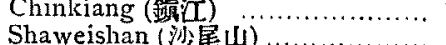 & $32 \times 2$ & $\operatorname{II} 930$ & 1041.8 \\
\hline Wuhu (茲湖) …...... & $\begin{array}{lll}3 I & 25 \\
31 & 22\end{array}$ & I22 I 5 & $934 \cdot 5$ \\
\hline Zikawei (俆家涎) & $3 \mathrm{I} 2$ & I $212 \mathrm{I}$ & $\begin{array}{l}1017.9 \\
1000.7\end{array}$ \\
\hline North Saddle (北馬鞍島) & 3052 & I 2240 & 746.7 \\
\hline Gutzluff（蒙司拉夫島）..... & 3050 & I22 10 & 823.8 \\
\hline 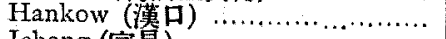 & 3033 & II 420 & 1276.1 \\
\hline Ichang (宣昌) $\ldots . . .$. & 3012 & II I I9 & $1059 \cdot 3$ \\
\hline Steep island (險島)... & 3012 & 12236 & 848.6 \\
\hline 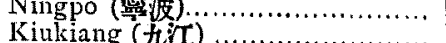 & 2958 & I2I 44 & $1375+3$ \\
\hline & 2944 & II 348 & 1.326 .4 \\
\hline
\end{tabular}




\begin{tabular}{|c|c|c|c|}
\hline Stations. & Iatitude. & Longitude. & $\begin{array}{l}\text { Annual } \\
\text { rainfall. }\end{array}$ \\
\hline Chunking (重量).. & $29^{\circ} 3 I^{\prime}$ & $\mathrm{IO} 4^{\circ} \mathrm{II}$ & 979.5 \\
\hline Wenchow (醞州)... & 280 & $\mathrm{r} 2035$ & I5OI.I \\
\hline 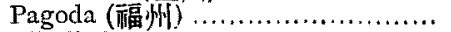 & 268 & $\operatorname{IIg} 38$ & 1208.6 \\
\hline Middledog $\ldots . . . . . . .$. & 2558 & I 202 & II I 4.9 \\
\hline Tournabout (牛山島) ..... & 2520 & II 556 & $100 \mathrm{r} .5$ \\
\hline Ockseu (身坻䊜) ........... & 2459 & II9 28 & 886.9 \\
\hline Amoy (俱阿) & 2427 & II 84 & 1073.0 \\
\hline Chapel island (東掟島) & 24 10 & II\& 13 & $8 \mathrm{I} 3.0$ \\
\hline Wuchow $($ 梧州 $)$ & 2329 & III 20 & I III. 5 \\
\hline Swatow (汕䫄). & 2320 & I 1643 & 1460.6 \\
\hline I.amocks (南澎島) & $23 \times 5$ & II 7 I 8 & IOOT.O \\
\hline Canton (廣東) .. & 237 & $113 \times 7$ & 1292.5 \\
\hline 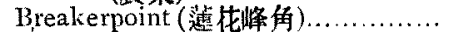 & 2256 & 11628 & 1549.6 \\
\hline Longchow (韵州) & 2222 & 10645 & IOIO.I \\
\hline Hongkong (香港)... & 22 I 8 & $1 I_{4}$ Io & 2005.0 \\
\hline Macao (溭門) & 22 II & Ir3 33 & I6 15.5 \\
\hline 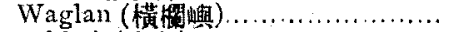 & 2210 & II 330 & 1209.9 \\
\hline Pakhoi (北海) . & 2129 & 1096 & I 979.9 \\
\hline Kinngchow & 203 & IIO 20 & I288. I \\
\hline
\end{tabular}

In Northern China, the amount of rainfall is generally below $100 \mathrm{~cm}$ as in our Hokkaido. The provinces of Shangtung are peculiarly liable to drought with consequent severe famine. But the valley of the Yangtsekiang and Southern China are wet and fertile. In general, the annual rainfall decreases from the south to the north; thus Pokhoi in the gulf of Tonking has $188 \mathrm{~cm}$. of rainfall; Foochow I2I cm; Zikawei IOI $\mathrm{cm}$; Shangtung promontory $9^{\mathrm{I}}$ and Peking $68 \mathrm{~cm}$. The annual rainfall also decreases from the coast towards the interior of the Empire. This can be clearly seen from the observations made at the raingauge stations in the valley of the Yangtsekiang. Thus Chinkiang has $\mathrm{IO}_{4} \mathrm{~cm}$. of yearly rainfall, Wuhu I02 cm., Kiukiang $133 \mathrm{~cm}$., Hangkow Io6 cm., Ichang 98 and Chonking $98 \mathrm{~cm}$.

In China, the annual rainfall is subject to very large fuctuations as Prof. Supan has already remarked. In northern portions of the Empire this is especially the case, but it may be also observable in Central China. We give below the series of annual rainfall for Peking in Northern China and Hangkow in Central China. 


$\begin{array}{lcc} & 4 & \\ \text { Yenr. } & \text { Teking. } & \text { Irangkow. } \\ 1890 & 992 & \text { I } 48.0 \\ 1891 & 116.1 \\ 1892 & 169 & 1298.0 \\ 1893 & 868 & 1407.8 \\ 1894 & 1084 & 1318.3 \\ 1895 & 1009 & 923.2 \\ 1896 & 370 & \text { I } 517.1 \\ 1897 & 684 & \text { I } 503.4 \\ 1899 & 674 & 1130.3 \\ 1899 & 557 & 1355.0\end{array}$

In Korea, the annual rainfall is about $90 \mathrm{~cm}$ on the west coast while it is generally above $100 \mathrm{~cm}$ on the east and south coasts. Thus there is a marked difference on the both sides of the central mountain ranges which constitute the back bones of the Peninsula Empire.

3. Ammal periods.-In China, the annual variation is very pronounced, of which we may distinguish two different types of variations, that is to say, northern type and southern type. In Northern China where the northern type of rainfall predominates, rainfall mostly happens in August or July, and February is the driest month. The Summer is very wet and fertilizing while the Winter is dry and cold. Most part of annual rainfall falls during Summer, and only a small part falls in Winter. In Southern China the wettest month is June and the driest December.

In Korea there are also two types of variations. In the northern portion of the Empire we have the greatest monthly rainfalls in the August, and the least in December to February. In the southern part, the June has most plentiful rainfall and the February the least.

We give in the Table II the mean monthly rainfalls for the stations, not taking into the account the unequal length of the months:- 


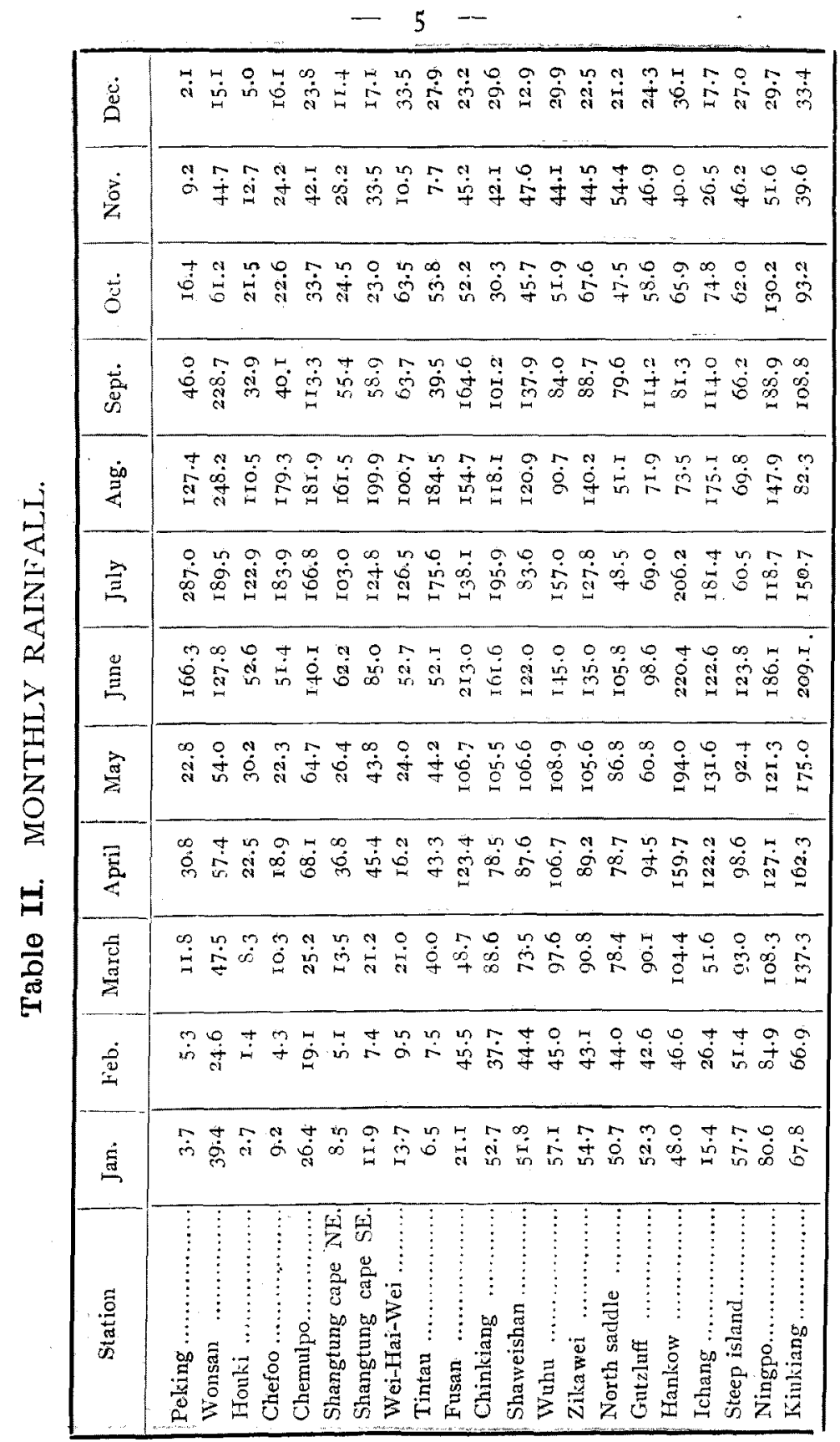




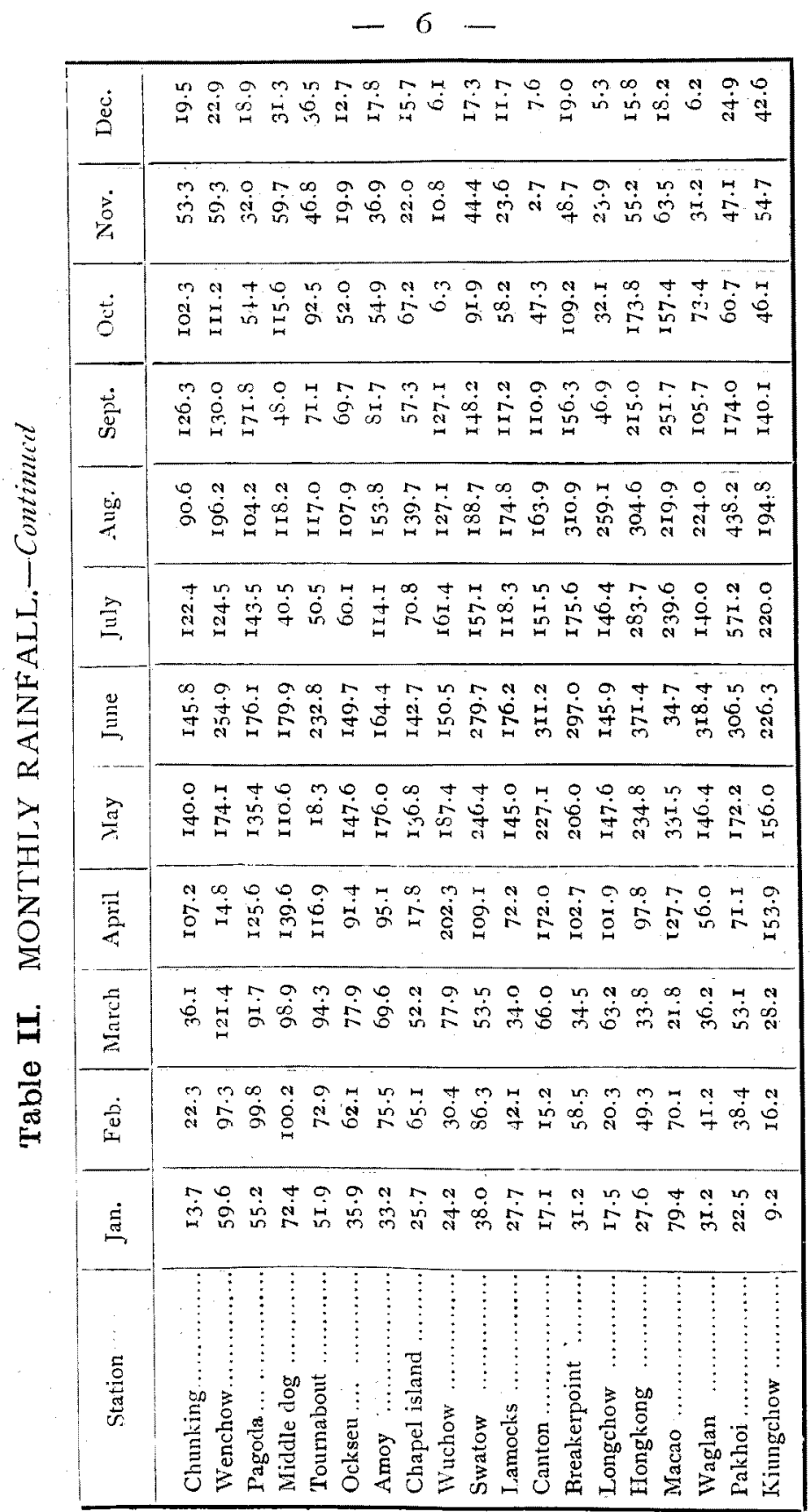




\section{- $7-$}

4. Number of rainy days.--Of days with rain here given are meant those on which the amount of fall is measured by $0.1 \mathrm{~mm}$ or more. In some climatological point of view, such trifle fall would be of little importance, but we have adopted the usual mode of counting the days with precipitation, on account of being capable of strict comparison with those in Japan and neighbouring countries.

The number of rainy days is greatest on the coast from Foochow to Shanghai, and decreases there towards the north and south. The coast of Central China has I 20 days of precipitation in average, Southern China 80 days and Northern China 60 days.

Rainy days are generally numerous during the warmer seasons and scanty in the colder seasons. The difference between the both seasons is very remarkable in Northern China. In Central China and the valley of the Yangtsekiang, however, rainy season begins in the April and continues to June, as in Japan proper where the rainy period in the early summer is commonly known as the season of the plum rain, so called because then the plums are getting ripe. In Korea, the number of rainy days is greatest on the west coast and least on the north-east coast. Thus, Chemulpo has 84 rainy days in a year, Fusan 76 , and Wonsan 64 . The rainy days are generally numerous in summer than in winter.

The following table contains the number of rainy days for each month and year :- 


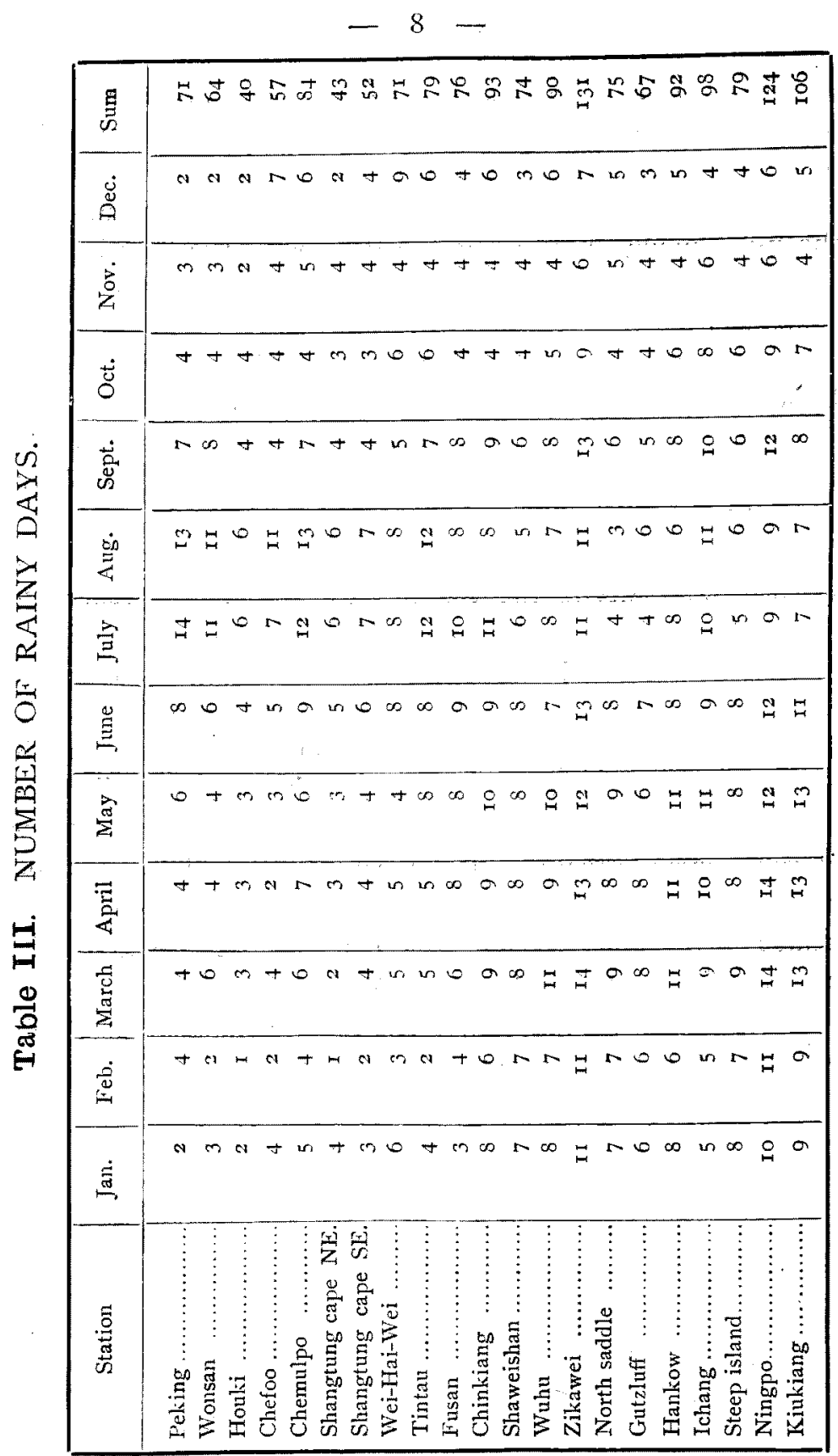




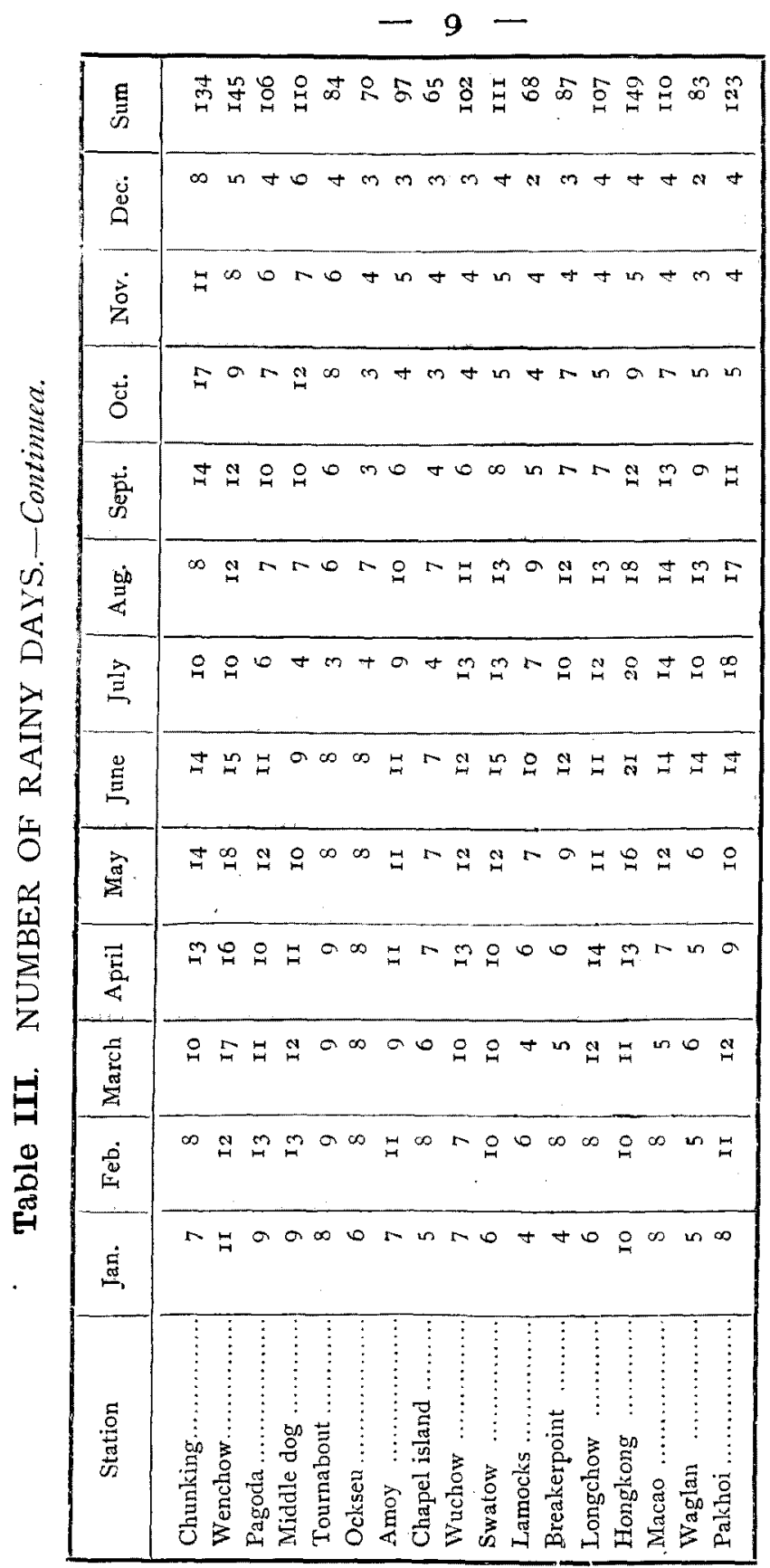


5. Groatest daily rainfall.-In China, heavy rainfall is rather rare phenomena, and such abundant down pour of rain as we often experience in this country occurs very rarely in the Celestial Empire. But falls of $100 \mathrm{~mm}$. in 24 hours are not rare, and most of these heavy falls happen during the four warmer months from April to August. We give here some of the instances of heavy rainfall leaving the further instances to the table IV :-

Stations.

Turn about.

Breaker point.

Turn about.

Swatow.

Wuchow.

Turn about.

Breaker point.

Breaker point.

Ockseu.
Amounts.

$363 \cdot 3$

360.2

292.2

270.7

252.3

213.4

219.3

208.3

200.7
Dates.

$\begin{array}{rlr}6 & \text { June } & \mathbf{1} 894 \\ 22 & \text { May } & \mathbf{1} 893 \\ 8 & \text { September } & \mathbf{1} 892 \\ 23 & \text { May } & \text { I } 893 \\ 22 & \text { May } & \text { I } 893 \\ 19 & \text { May } & 1895 \\ 7 & \text { October } & 1894 \\ \text { II } & \text { August } & \text { I } 897 \\ 8 & \text { September } & 1892\end{array}$

In Korea, heavy rainfall also seldom occurs. Fall of more than $100 \mathrm{~mm}$ is a rare phenomena. We have only a single instance of heavy rainfall more than $200 \mathrm{~mm}$. The following small table contains the greatest daily rainfall more than 120 mm observed at Fusan, Chemulpo and Wonsan :-

Stations.

Wonsan.

Fusan.

Wonsan.

Fusan,
Amounts.

382.5

I 68.0

I 64.6

I 29.0
Dates.

4 September I 893

22 September 1899

6 September I90 I

25 June I $89^{8}$ 


\begin{tabular}{|c|c|}
\hline$\stackrel{\ddot{~}}{\dot{~}}$ & 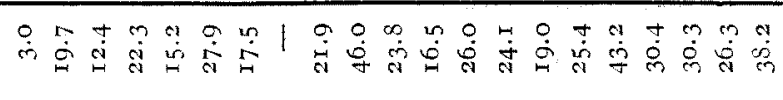 \\
\hline 宫 & 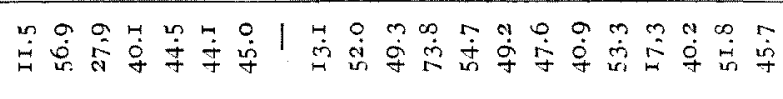 \\
\hline ث் & 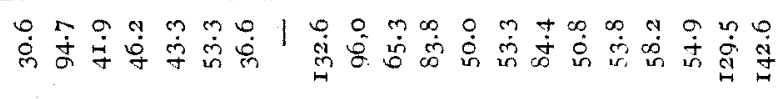 \\
\hline 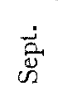 & 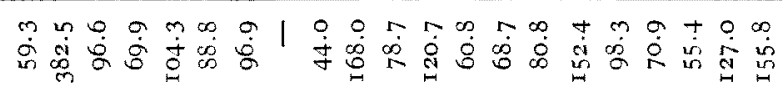 \\
\hline$\stackrel{\dot{\infty}}{\rightleftarrows}$ & 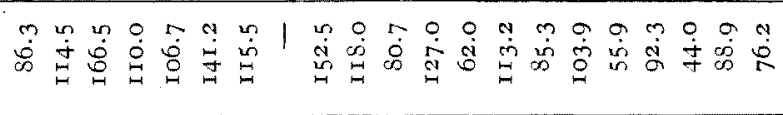 \\
\hline$\geqq$ & 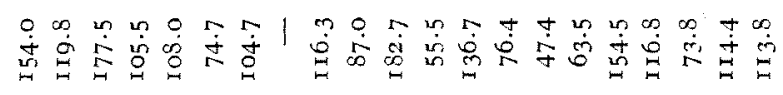 \\
\hline$\stackrel{\varrho}{\Xi}$ & 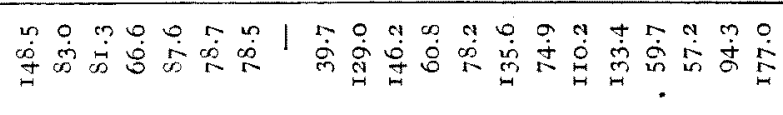 \\
\hline 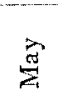 & 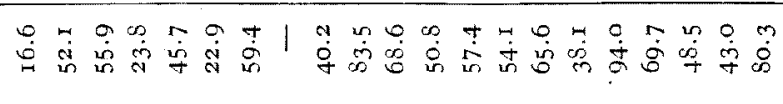 \\
\hline 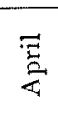 & 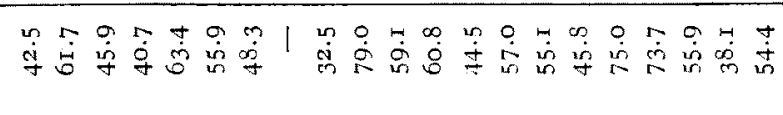 \\
\hline 胥 & 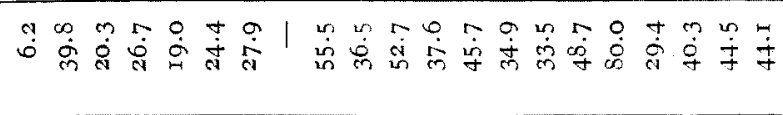 \\
\hline$\stackrel{\dot{0}}{\stackrel{0}{L}}$ & 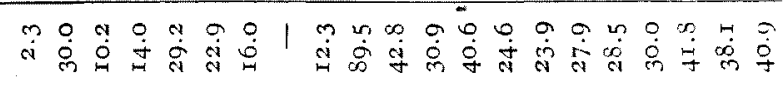 \\
\hline$\stackrel{\dot{\Xi}}{\stackrel{(}{5}}$ & 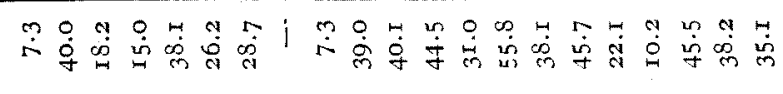 \\
\hline$\stackrel{\Xi}{\stackrel{\Xi}{E}}$ & 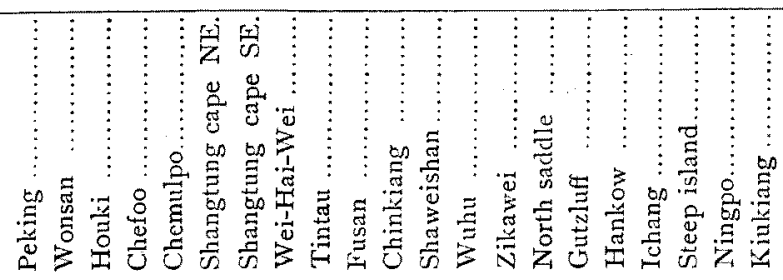 \\
\hline
\end{tabular}




\begin{tabular}{|c|c|}
\hline$\dot{\tilde{\Xi}}$ & 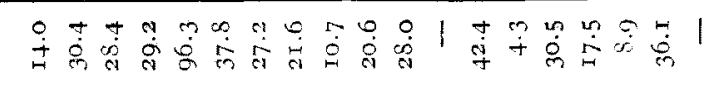 \\
\hline 它 & 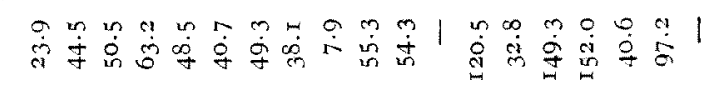 \\
\hline 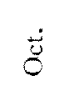 & 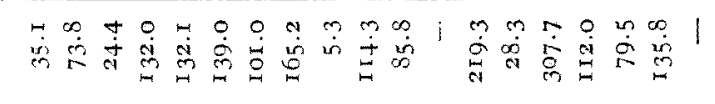 \\
\hline 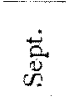 & 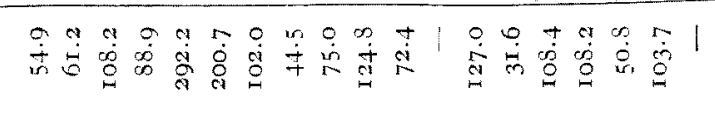 \\
\hline$\dot{\ddot{g}}$ & 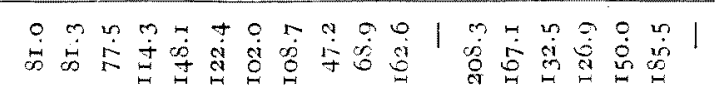 \\
\hline$\stackrel{\Xi}{\Xi}$ & 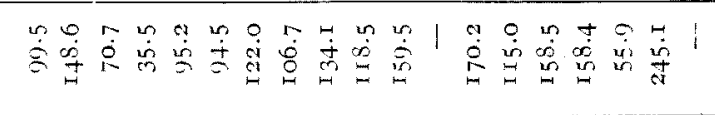 \\
\hline$\stackrel{巳}{\Xi}$ & 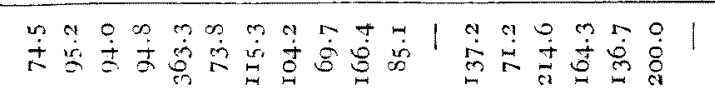 \\
\hline$\stackrel{\mathrm{e}}{\frac{\mathrm{J}}{2}}$ & 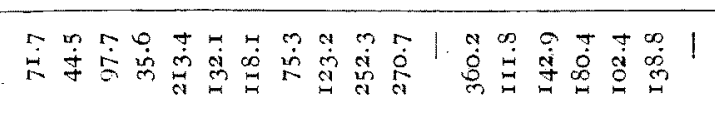 \\
\hline 窟 & कo \\
\hline 总 & 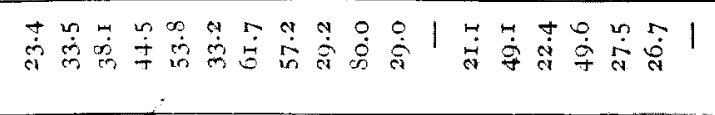 \\
\hline$\stackrel{\circ}{2}$ & 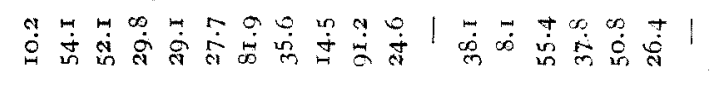 \\
\hline 离 & 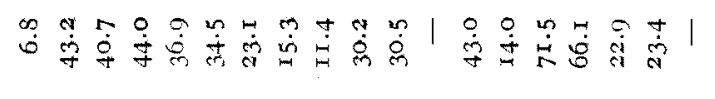 \\
\hline 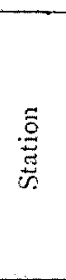 & 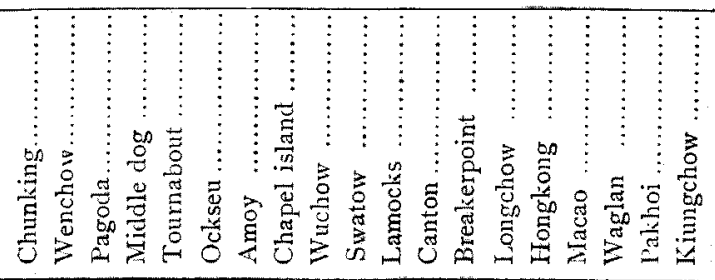 \\
\hline
\end{tabular}

